\title{
TERMS USED TO DESIGNATE \\ EXPERIMENTAL SITES IN HAWAII
}

Central Maui. An irrigated plantation on Maui.

Ewa. An irrigated plantation on the south coast of Oahu.

Hamakua Coast. Plantations on the northeast coast of Hawaii Island (Honokaa and Paauhau).

Hilo Coast. Plantations on the northeast coast of Hawaii Island (Hilo, Onomea, Pepeekeo, and Hakalau).

Kailua. A substation of HSPA (Hawaiian Sugar Planters' Association) on Oahu.

Ka'u. Pahala and Naalehu plantations on the southwest coast of Hawaii Island.

Kilauea. An irrigated plantation on the north coast of Kauai.
Kohala. A plantation on the northern tip of Hawaii Island.

Lahaina. A plantation town in West Maui.

Naalehu. See Ka'u.

Olokele. An irrigated plantation on the southwest coast of Kauai.

Pahala. See Ka'u.

Waialua. An irrigated plantation on the northwest coast of Oahu.

Wailuku. An irrigated plantation in west central Maui.

Waipio. A substation of HSPA in central Oahu.

\section{INDEXES, ABBREVIATIONS, AND SPECIAL TERMS USED IN CROP LOGGING}

\section{INDEXES}

Primary Index. The total sugars content of the young sheaths expressed as percentage of dry weight.

Moisture Index (MI). The $\mathrm{H}_{2} \mathrm{O}$ content of the young sheaths $+3,+4,+5,+6$ expressed as percentage of green weight (also called Sheath Moisture Index).

Sheath Moisture Index. See Moisture Index.

Normal Moisture Index. Derived by equation based on several factors from best yielding crops of the particular variety.

Nitrogen Index (NI). The total nitrogen content of the green tissue taken from the center of leaf blades $+3,+4,+5,+6$ expressed as percentage of dry weight.

Normal Nitrogen Index (NN). The Nitrogen Index calculated by an equation for the moisture index and age of the particular variety as taken from excellent crops, expressed as percentage of dry weight.

Standard Nitrogen Index (SNI). The Nitrogen Index calculated for standard moisture levels and ages for a given variety.
Phosphorus Index (PI). The phosphorus content of the young sheaths expressed as percentage of sugar-free dry weight.

5th $\mathrm{P}$. The phosphorus content of the 5 th mature internode counting down from the oldest living leaf, expressed as percentage of dry matter.

Standard Phosphorus Index (SPI). The Phosphorus Index standardized to given moisture and primary index levels.

Amplified Phosphorus Index (API). The product of the Standard Phosphorus Index and the 5th P as whole numbers.

Potassium Index (KI). The potassium content of the young sheaths expressed as percentage of sugarfree dry weight.

$\mathrm{K}-\mathrm{H}_{2} \mathrm{O}$ Index $\left(\mathrm{K}-\mathrm{H}_{2} \mathrm{O}\right)$. The potassium content of the young sheaths $+3,+4,+5,+6$ expressed as percentage of tissue moisture.

Other indexes. Indexes for all other elements are expressed as percentages or parts per million of sugar-free dry weight of the young sheaths. 